\title{
Multi-element Analysis of Vitreous Humor Samples by ICP-MS and ICP-OES
}

\author{
M. Vázquez ${ }^{a}$, I. Ibarra ${ }^{a}$, A. Sibón ${ }^{b}$, and M.D. Pérez-Cárceles ${ }^{c, *}$ \\ a Assistance Service of Technological Research, Technical University of Cartagena, Murcia, Spain \\ ${ }^{b}$ Forensic Pathology Service, Institute of Legal Medicine, Cádiz, Spain \\ c Department of Legal and Forensic Medicine, Biomedical Research Institute (IMIB-Arrixaca), \\ Regional Campus of International Excellence “Campus Mare Nostrum”, Faculty of Medicine, \\ University of Murcia, E-30100 Spain
}

\section{INTRODUCTION}

The analysis of metals in clinical fluids such as whole blood, serum, and urine has been performed for many years to provide information on toxicity and as a diagnostic tool for a number of ailments. Trace element determination in whole blood and serum can be applied in forensic medicine to diagnose the cause of death (1-4).

Vitreous humor has also been used for postmortem biochemical investigations for several decades. The vitreous humor $(\mathrm{VH})$ of the eye represents an isolated fluid that is less vulnerable than blood to rapid chemical changes or contamination. It is also superior to other body fluids as it undergoes postmortem changes more slowly and is technically easier to obtain. Therefore, vitreous humor is well suited for use in post-mortem biochemical investigations. The vitreous humor consists of gel-like collagen fibrils and fluids. The resulting high viscosity makes sample pre-treatment possible $(5,6)$.

To our knowledge, previous studies in salt water drowning deaths demonstrated an observable elevation of post mortem vitreous sodium and chloride levels $(7,8)$. However, according to our research there are few references in the literature where chemical elements were analyzed and studied in vitreous humor as potential markers to diagnose drowning.

The aim of the present study was to identify a simple proedure for

${ }^{*}$ Corresponding autbor.

E-mail: mdperez@um.es

Tel: +34868887018

\section{ABSTRACT}

This work aims to find a simple procedure for the determination of multiple elements in vitreous humor to be used as a complementary tool in forensic science to diagnose drowning. Fourteen elements ( $\mathrm{Li}, \mathrm{Mn}, \mathrm{Co}$, $\mathrm{Cu}, \mathrm{Zn}, \mathrm{As}, \mathrm{Se}, \mathrm{Sr}, \mathrm{Mo}, \mathrm{Cd}, \mathrm{Fe}$, $\mathrm{Mg}, \mathrm{K}$, and $\mathrm{Ca}$ ) were determined by inductively coupled plasma mass spectrometry (ICP-MS) and inductively coupled plasma optical emission spectrometry (ICPOES) to establish a comparison between both techniques and to determine which is the most suitable for diagnostic purposes. Certified reference materials (Seronorm Trace Elements Serum L-2 and Seronorm Trace Elements Whole Blood L-1) were subjected to three preparation methods: digestion in the microwave digestion system (Method 1 and Method 2) and dilution with ultrapure water (Method 3), then analyzed by ICP-MS. The results suggest that the dilution method is the pretreatment of choice for multielement determination. The two diluted reference materials were analyzed by ICP-OES, and better results were obtained with ICPMS than with ICP-OES. The analyses performed on dilute vitreous humor samples show that ICP-OES is only suitable for fluids with high element concentrations, while ICP-MS has high sensitivity, low detection limits, and allows the measurement of trace and ultra-trace elements in biological matrices making it the technique of choice for elemental analysis of vitreous humor samples. the determination of multiple elements in vitreous humor by inductively coupled plasma mass spectrometry (ICP-MS) and inductively coupled plasma optical emission spectrometry (ICP-OES) to be used as a complementary tool in forensic science.

The first section presents three methods of sample preparation for the determination of the concentrations of 14 elements [lithium (Li), manganese (Mn), cobalt (Co), cop$\operatorname{per}(\mathrm{Cu})$, zinc $(\mathrm{Zn})$, arsenic (As), selenium (Se), strontium ( $\mathrm{Sr}$ ), molybdenum (Mo), cadmium (Cd), iron (Fe), magnesium (Mg), potassium $(\mathrm{K})$ and calcium $(\mathrm{Ca})]$ in certified reference materials (CRMs), serum, and whole blood using ICPMS. The reference materials were subjected to a simple dilution with ultrapure water and acid digestion in a microwave digestion system. These sample preparation methods were compared for improvement of the analytical productivity when measuring multiple elements using ICP-MS (9-11).

In the second section, the CRMs were analyzed for their concentrations of $\mathrm{Li}, \mathrm{Mn}, \mathrm{Co}, \mathrm{Cu}, \mathrm{Zn}$, As, Se, $\mathrm{Sr}, \mathrm{Mo}, \mathrm{Cd}, \mathrm{Fe}, \mathrm{Mg}, \mathrm{K}$, and $\mathrm{Ca}$ by ICP-OES, and the results obtained were compared with the results by ICP-MS to establish which of the two analytical techniques is most suitable for the analysis of biological fluids. Finally, the chemical elements studied were analyzed in vitreous humor samples using the two analytical techniques.

\section{EXPERIMENTAL}

\section{Instrumentation}

An Agilent 7500ce inductively 
coupled plasma mass spectrometer (Agilent Technologies, CA, USA) was used for the determination of the analytes. The ICP-MS instrument was optimized using a tuning solution containing ${ }^{7} \mathrm{Li},{ }^{59} \mathrm{Co},{ }^{89} \mathrm{Y}$, and ${ }^{205} \mathrm{Tl}(1 \mu \mathrm{g} / \mathrm{L})$ from High Purity Standards (Charleston, SC, USA) for sensitivity (high signal/background ratio) across the mass range and low interference levels $\left(\mathrm{CeO}^{+} / \mathrm{Ce}^{+}<1 \%\right.$ and $\left.\mathrm{Ce}^{2+} / \mathrm{Ce}^{+}<3 \%\right)$. The instrumental parameters are listed in Table I.

An Ethos Plus Milestone microhigh pressure rotor was used for sample digestion.

Certified reference materials and vitreous humor samples were analyzed using a PerkinElmer ${ }^{\circledR}$ Optima $^{\text {TM }}$ 8300 inductively coupled plasma optical emission spectrometer with radial and axial configuration (PerkinElmer, Inc., Shelton, CT, USA). The instrumental operating conditions are listed in Table II.

\section{Standard Solutions and Reagents}

All solutions were prepared with ultrapure water (18.2 M $\Omega$-cm resistivity) obtained by purifying dis-

TABLE I

ICP-MS Operating Conditions

\begin{tabular}{lr}
\hline RF Power & $1500 \mathrm{~W}$ \\
Sample depth & $8 \mathrm{~mm}$ \\
Carrier gas & $1.0 \mathrm{~L} / \mathrm{min}$ \\
Makeup gas & $0.3 \mathrm{~L} / \mathrm{min}$ \\
Spray chamber temp. & $2{ }^{\circ} \mathrm{C}$ \\
Extract 1 & $8 \mathrm{~V}$ \\
Extract 2 & $-58.5 \mathrm{~V}$ \\
Omega bias & $-8 \mathrm{~V}$ \\
Omega lens & $3 \mathrm{~V}$ \\
Cell entrance & $-50 \mathrm{~V}$ \\
QP focus & $-14 \mathrm{~V}$ \\
Cell exit & $-80 \mathrm{~V}$ \\
Octopole bias & $-19 \mathrm{~V}$ \\
QP bias & $-17.3 \mathrm{~V}$ \\
Cell gas flow & $4.0 \mathrm{~mL} / \mathrm{min} \mathrm{He}$ \\
\hline
\end{tabular}

tilled water with the Elix 3/Milli-Q ${ }^{\circledR}$ Element System (Millipore Corporation, USA). Hiperpur ${ }^{\circledR}$ nitric acid, (15.014M) was purchased from Panreac, Spain. Standard solutions containing $1000 \mathrm{mg} / \mathrm{L}$ of each element were purchased from High Purity Standards (Charleston, SC, USA) and used to prepare calibration standards for ICP-MS and ICPOES. Working standards were prepared in $0.224 \mathrm{M} \mathrm{HNO}_{3}$ and used without further purification.

The internal standard solutions of $1000 \mathrm{mg} / \mathrm{L}$ scandium (Sc), gallium (Ga), rhodium (Rh), and thallium ( $\mathrm{Tl}$ ) were purchased from High Purity Standards (Charleston, SC, USA). The argon gas used was of spectral purity.

Certified reference materials Seronorm Trace Elements Serum L-2 and Seronorm Trace Elements Whole Blood L-1 were purchased from SERO AS (Billingstad, Norway).

For digestion, $\mathrm{HNO}_{3}(15.014 \mathrm{M})$, $\mathrm{HCl}(12.08 \mathrm{M})$ technical grade, and $\mathrm{H}_{2} \mathrm{O}_{2}$ (9.8M) (Panreac AppliChem, Spain) were used.

TABLE II ICP-OES Operating Conditions

\begin{tabular}{lr}
\hline RF Power & $1500 \mathrm{~W}$ \\
Plasma gas flow rate & $8 \mathrm{~L} / \mathrm{min}$ \\
Auxiliary gas flow rate & $0.2 \mathrm{~L} / \mathrm{min}$ \\
Nebulizer gas flow rate & $0.7 \mathrm{~L} / \mathrm{min}$ \\
Sample flow rate & $1 \mathrm{~mL} / \mathrm{min}$ \\
View mode & Axial - Radial \\
Source equilibration time & $15 \mathrm{~s}$ \\
Read delay & $60 \mathrm{~s}$ \\
Read & Peak area \\
Replicates & 3 \\
Background correction & $2-p o i n t$ \\
\multicolumn{2}{l}{ (manual point correction) } \\
Purge gas & Argon \\
Shear gas & Air \\
Gas & Argon \\
\hline
\end{tabular}

\section{Sampling and Sample Preparation}

The vitreous humor samples were collected during medical-legal autopsies performed in the Institute of Forensic Medicine, Cádiz (southern Spain). The study was approved by the Ethics Committee of the Institute of Forensic Medicine.

The vitreous humor was obtained using a 20-gauge needle and sampled separately from both ocular bulbs. The vitreous humor sample was gently withdrawn from each eye with a syringe and placed into a 13-mL sample tube (polypropylene container, screw top). To prevent degradation, the samples were stored at $-70^{\circ} \mathrm{C}$. All specimens, with a total volume of at least $2 \mathrm{~mL}$ each, were thawed at room temperature and each sample was treated separately.

The certified reference materials Seronorm Trace Elements Serum L-2 and Seronorm Trace Elements Whole Blood L-1 were subjected to three preparation methods using Method 1, Method 2, and Method 3 and analyzed by ICP-MS

Method 1

Microwave digestion with $\mathrm{HNO}_{3}$, $\mathrm{HCl}$, and $\mathrm{H}_{2} \mathrm{O}_{2}$.

Method 2

Microwave digestion with $\mathrm{HNO}_{3}$.

Method 3

Dilution with ultra-pure water. The whole blood reference sample was diluted 20-fold and the serum reference sample was diluted 10 -fold.

Moreover, the whole blood reference sample, diluted 20 -fold, and the serum reference sample, diluted 10-fold, were analyzed by ICP-OES. Finally, vitreous humor samples, diluted 10-fold, were analyzed by both analytical techniques.

\section{Sample Digestion Procedure}

Microwave digestion of the CRMs was performed in an Ethos Plus Milestone microwave oven 
with a Model HPR-1000/10S highpressure rotor.

The most convenient digestion procedure is microwave digestion. This method greatly reduces analysis time and its closed operation method minimizes or eliminates contamination, prevents loss of volatile species (i.e., Se and As), and uses a lower sample size and less reagent, thus aiding operator safety. Additional benefits include the ability to deal with complex matrices that do not easily lend themselves to dissolution. Laboratory microwave ovens with pressure and temperature control also tend to yield more controlled and reproducible results than the conventional digestion methods.

Microwave energy is absorbed by dipole rotation and ionic conductance, causing rapid heating of not only the aqueous phase but also of the sample itself. The acid used was nitric acid, which is the most common acid for oxidation of organic matrices, dissolves most elements, forms soluble nitrates, although with exceptions, and for this reason it is often mixed with hydrochloric acid. For its part, hydrogen peroxide is an oxidizing agent and added to nitric acid reduces the nitrous vapors and accelerates digestion of the organic samples $(12,13)$.

Although ICP-MS has proven to be the best multi-elemental analytical technique for sensitive and rapid determination of trace elements, the presence of high acid content in the samples poses problems of plasma instability and even extinction. The choice of sample digestion may also be the main source of systematic error. Dilution is often employed to overcome the problem, but it can affect the sensitivity of the method. Therefore, the CRMs and the samples were subjected to another preparation method using direct dilution with ultrapure water.
Three sample digestion procedures were used:

\section{Method 1}

The CRM samples ( $0.50 \mathrm{~g})$ were placed in reaction vessels and digested with $9 \mathrm{~mL}$ of $\mathrm{HNO}_{3}$ (15.014M), $3 \mathrm{~mL}$ of $\mathrm{HCl}(12.08 \mathrm{M})$, and $2 \mathrm{~mL}$ of $\mathrm{H}_{2} \mathrm{O}_{2}(9.8 \mathrm{M})$ in the microwave digestion system.

\section{Method 2}

The CRM samples $(0.50 \mathrm{~g})$ were placed in reaction vessels and digested with $9 \mathrm{~mL}$ of $\mathrm{HNO}_{3}$ $(15.014 \mathrm{M})$ in the microwave digestion system.

\section{Method 3}

The digestion conditions for the microwave system are listed in Table III. After cooling, the final solutions were brought to $100 \mathrm{~mL}$ volume with ultrapure water. A blank digestion was carried out in the same way (12-13).

\section{ICP-MS Determination Procedure}

An Agilent 7500ce ICP-MS with integrated autosampler (I-AS) was used. The He gas was introduced into the collision cell. Polyatomic interferences were removed through collision-induced dissociation and kinetic energy discrimination.

A MicroMist nebulizer (Glass Expansion) and standard quartz Scott-type double-pass spray chamber were used. A high-precision peristaltic pump with three channels and 10 roller pumps allows the precise computer-controlled pumping of the sample, internal standard,

TABLE III Microwave Program

\begin{tabular}{cccc}
\hline Step & $\begin{array}{c}\text { Time } \\
(\min .)\end{array}$ & $\begin{array}{c}\text { Temp. } \\
\left({ }^{\circ} \mathrm{C}\right)\end{array}$ & $\begin{array}{c}\text { Power } \\
(\mathrm{W})\end{array}$ \\
\hline 1 & 3 & 100 & 700 \\
2 & 10 & 165 & 700 \\
3 & 5 & 190 & 700 \\
4 & 15 & 190 & 700 \\
\hline
\end{tabular}

and spray chamber drainage. The pump speed was set at 0.2 revolutions per second (rps) during the analysis and washout in order to minimize overloading the sample introduction system and the plasma with the matrix components. The spray chamber was Peltier-cooled to $2{ }^{\circ} \mathrm{C}$ to ensure temperature stability and to reduce water vapor present in the nebulizer gas flow.

A quartz torch with a $2.5-\mathrm{mm}$ diameter injector and Shield Torch Technology (Agilent Technologies, CA, USA) and nickel (Ni) cones were used at all times.

All instrumental conditions (Table I) were controlled by Agilent MassHunter Work Station Software for ICP-MS and optimized daily while aspirating a tuning solution.

Optimized tuning involves maximizing the analyte signal(s) while minimizing the interferences. The tuning was carried out using a standard tuning solution as recommended by Agilent Technologies $(1 \mu \mathrm{g} / \mathrm{L}$ of $\mathrm{Li}, \mathrm{Co}, \mathrm{Y}, \mathrm{Ce}$, and $\mathrm{Tl}$ in $\mathrm{HNO}_{3} 0.224 \mathrm{M}$ ) to achieve higher intensities. The choice of these five elements allows the mass spectrometer and the instrument performance to be tested over the whole mass range. Ce was used since it shows a high oxide ion generation rate due to its high affinity for oxygen. Therefore, Ce is a good marker for the robustness of the plasma, and its use is recommended for tuning applications in which the suppression of oxide ion generation is desired. The oxide ratio of $\mathrm{CeO}^{+} /$ $\mathrm{Ce}^{+}(156 / 140)$ and doubly charged species ratio of $\mathrm{Ce}^{2+} / \mathrm{Ce}^{+}(70 / 140)$ were maintained below $0.7 \%$ and $1.4 \%$, respectively.

The chosen IS elements (Sc, Ga, $\mathrm{Rh}$, and $\mathrm{Tl}$ ) were added to all of the samples, calibration standards, and blanks at the same concentration $(40 \mu \mathrm{g} / \mathrm{L})$ to obtain information on changes in sensitivity of different mass regions. 
All analytes were measured in helium mode. Quantitation of all isotopes was performed using the three central points of the spectral peaks. The integration times per point were adjusted to two seconds, thus obtaining better detection limits. Three replicates were made for each determination. The pump speed was set at 0.2 rps during the analysis and washout in order to minimize overloading the sample introduction system and the plasma with matrix components. The isotopes, internal standard used, instrument detection limits (IDL), and background equivalent concentration (BEC) are listed in Table IV.

The ICP-MS system was calibrated by the external standards method. Calibration curves were obtained by using at least eight multi-elemental calibration solutions including the calibration blank. The resulting calibration curves had linear regression coefficients in which $R^{2} \geq 0.999$ for each analyte. The measuring ranges of the calibration lines are listed in Table IV.

The calibration graph was determined at the beginning of the analytical sequence and was assessed by measuring a mid-range standard (depending on the elements) after the calibration curve every 10 samples and at the end of the run (to estimate the variation of the instrumental response and to check the quality of the analytical sequence). The entire analysis was considered valid if the mean concentration of the mid-range standard gave a value between 80 and $120 \%$ of the expected concentration. Otherwise, the run was stopped, the ICP-MS was reoptimized to obtain acceptable stability, and the analysis was performed again. For the purpose of contamination control, each series of measurements included a reagent blank.

\section{ICP-OES Determination Procedure}

A PerkinElmer ${ }^{\circledR}$ Optima $^{\mathrm{TM}} 8300$ ICP-OES with radial and axial configuration was used. The instrument was equipped with a $40 \mathrm{MHz}$ radio frequency source, Echelle grating with 79 lines per mm, SCD detector, plasma torch with a $2.0-\mathrm{mm}$ internal diameter injection, and a glass concentric nebulizer coupled to a glass cyclonic spray chamber. An interface (shear gas) that introduces a high air flow perpendicular to the torch was used to remove the low temperature at the end of the plasma. An AS-90 autosampler Plus (PerkinElmer, Inc.) system was used for the sample introduction. The instrumental operating conditions are listed in Table II. Table V lists the most sensitive analytical lines of the analytes without spectral interferences in the sample matrix used for the analysis (14-16).

The ICP-OES system was calibrated by the external standards method. Calibration curves were obtained using at least eight multielemental calibration solutions

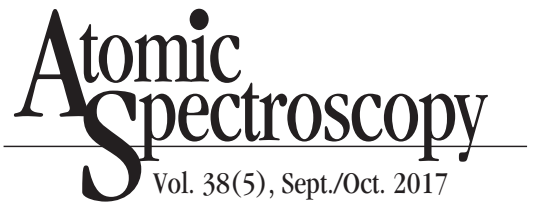

including the calibration blank. The standard solutions for the analysis were made up of concentrations for $\mathrm{Fe}, \mathrm{Ca}, \mathrm{Mg}$ and $\mathrm{K}$ of $0.5,1,5,10$, 25,50 , and $100 \mathrm{mg} / \mathrm{L}$; and for $\mathrm{Li}$, $\mathrm{Mn}, \mathrm{Co}, \mathrm{Cu}, \mathrm{Zn}$, Se, Sr and $\mathrm{Cd}$ of $0.05 \mathrm{mg} / \mathrm{L}, 0.1 \mathrm{mg} / \mathrm{L}, 0.5 \mathrm{mg} / \mathrm{L}$, $1.0 \mathrm{mg} / \mathrm{L}, 2.0 \mathrm{mg} / \mathrm{L}, 5.0 \mathrm{mg} / \mathrm{L}$ and $10 \mathrm{mg} / \mathrm{L}$. They were prepared with ultrapure water acidified with Hiperpur nitric acid (Panreac). The resulting calibration curves had linear regression coefficients in which $R^{2} \geq 0.999$ was used for each analyte.

The limit of detection (LOD) for each metal was calculated from the standard deviation for the determination of 10 independent analyses of a blank solution spiked with the metal at a level of lower concentration. The analytical results are listed in Table V.

As in ICP-MS, the calibration graph was determined at the beginning of the analytical sequence and was assessed by measuring the standards every 10 samples, and at the end of the run to check the quality of the analytical sequence again. For the purpose of contamination

TABLE IV

Analysis Parameters, Measurement Ranges, IDLs and BECs for the Analytes

\begin{tabular}{lccccc}
\hline Analyte & $\begin{array}{c}\text { Isotope } \\
\text { Monitored } \\
(\mathrm{m} / \mathrm{z})\end{array}$ & $\begin{array}{c}\text { Internal } \\
\text { Standard } \\
\text { Used }(\mathrm{m} / \mathrm{z})\end{array}$ & $\begin{array}{c}\text { Measurement } \\
\text { Range } \\
(\mu \mathrm{g} / \mathrm{L})\end{array}$ & $\begin{array}{c}\text { IDL } \\
(\mu \mathrm{g} / \mathrm{L})\end{array}$ & BEC \\
\hline $\mathrm{Li}$ & 7 & 45 & $0-200$ & 0.286 & 0.208 \\
$\mathrm{Mg}$ & 24 & 45 & $0-10000$ & 0.190 & 0.621 \\
$\mathrm{~K}$ & 39 & 45 & $0-10000$ & 3.957 & 31.50 \\
$\mathrm{Ca}$ & 44 & 45 & $0-10000$ & 3.219 & 15.71 \\
$\mathrm{Mn}$ & 55 & 71 & $0-200$ & 0.031 & 0.117 \\
$\mathrm{Fe}$ & 56 & 71 & $0-5000$ & 0.272 & 1.732 \\
$\mathrm{Co}$ & 59 & 71 & $0-200$ & 0.004 & 0.016 \\
$\mathrm{Cu}$ & 63 & 71 & $0-200$ & 0.109 & 0.556 \\
$\mathrm{Zn}$ & 66 & 71 & $0-200$ & 0.789 & 3.017 \\
$\mathrm{As}$ & 75 & 71 & $0-200$ & 0.060 & 0.086 \\
$\mathrm{Se}$ & 78 & 71 & $0-200$ & 0.655 & 0.982 \\
$\mathrm{Sr}$ & 88 & 103 & $0-200$ & 0.030 & 0.132 \\
$\mathrm{Mo}$ & 95 & 103 & $0-200$ & 0.007 & 0.005 \\
$\mathrm{Cd}$ & 111 & 103 & $0-200$ & 0.002 & 0.004 \\
\hline
\end{tabular}


control, each series of measurements included a reagent blank.

\section{Analysis of Certified Reference Materials}

The certified reference materials Seronorm Trace Elements Serum L-2 and Seronorm Trace Elements Whole Blood L-1 were subjected to three preparation methods: digestion in the microwave digestion system (Method 1 and Method 2) and dilution with ultrapure water (Method 3), then analyzed by ICPMS using the conditions described in Tables I and IV. These materials were chosen because they represented different clinical matrices and contained a wide range of analytes of interest ranging in concentration levels from $\mathrm{ng} / \mathrm{L}$ to $\mathrm{mg} / \mathrm{L}$. The element concentrations are listed in Table IV.

In addition, the two certified reference materials were prepared by dilution with ultrapure water and analyzed by ICP-OES using the conditions described in Tables II and V.
The results of theese tables are reported in Table VI.

\section{Analysis of the Collected Human Samples}

Twelve human vitreous humor samples were prepared by dilution with ultrapure water and analyzed by ICP-MS (Table VII) and ICP-OES (Table VIII). The results were compared using linear regression analysis. Statistical significance was defined as $p<0.05$. Statistical analyses were performed using IBM ${ }^{\circledR}$ SPSS ${ }^{\circledR}$ Statistics 23 software.

\section{RESULTS AND DISCUSSION}

\section{Analyses of Certified Reference Materials}

The results of the analyses of the reference materials performed by ICP-MS and compiled in Tables IX and $\mathrm{X}$ show good agreement of the dilution method (Method 3) with the recommended values for Fe, $\mathrm{Mg}, \mathrm{K}, \mathrm{Ca}, \mathrm{Mn}, \mathrm{Cu}, \mathrm{Zn}$, and $\mathrm{Sr}$ in both whole blood and serum,
TABLE V

Analytical Wavelengths (nm), Limit of detection (LOD) and Limit of Quantification (LOQ)

\begin{tabular}{lcrr}
\hline $\begin{array}{l}\text { Ele- } \\
\text { ments }\end{array}$ & $\begin{array}{c}\text { Analytical } \\
\text { Wave- } \\
\text { lengths } \\
(\mathrm{nm})\end{array}$ & $\begin{array}{c}\text { LOD } \\
(\mu \mathrm{g} / \mathrm{L})\end{array}$ & $\begin{array}{c}\text { LOQ } \\
(\mu \mathrm{g} / \mathrm{L})\end{array}$ \\
\hline $\mathrm{Li}$ & 670.784 & 6.7 & 22 \\
$\mathrm{Mg}$ & 285.213 & 6.1 & 20 \\
$\mathrm{~K}$ & 766.490 & 4.1 & 14 \\
$\mathrm{Ca}$ & 317.933 & 4.8 & 16 \\
$\mathrm{Mn}$ & 257.610 & 5.0 & 17 \\
$\mathrm{Fe}$ & 238.204 & 6.6 & 22 \\
$\mathrm{Co}$ & 228.616 & 5.6 & 19 \\
$\mathrm{As}$ & 188.979 & 30.4 & 101 \\
$\mathrm{Mo}$ & 202.031 & 18.4 & 61 \\
$\mathrm{Cu}$ & 327.393 & 8.7 & 29 \\
$\mathrm{Zn}$ & 206.200 & 5.1 & 17 \\
$\mathrm{Se}$ & 196.026 & 30.9 & 103 \\
$\mathrm{Sr}$ & 407.771 & 6.4 & 21 \\
$\mathrm{Cd}$ & 228.802 & 5.5 & 18 \\
\hline
\end{tabular}

TABLE VI

Results of ICP-OES Analysis. Certified and Found Values of Element Concentrations in Seronorm Trace Elements Whole Blood L-1 and Seronorm Trace Elements Serum L-2

\begin{tabular}{|c|c|c|c|c|c|c|}
\hline \multirow{3}{*}{ Elements } & \multicolumn{3}{|c|}{ Seronorm Trace Elements Whole Blood L-1 } & \multicolumn{3}{|c|}{ Seronorm Trace Elements Serum L-2 } \\
\hline & \multicolumn{2}{|c|}{ Certified Value } & \multirow[b]{2}{*}{$\begin{array}{l}\text { Value Found } \\
\text { (RSD) }\end{array}$} & \multicolumn{2}{|c|}{ Certified Value } & \multirow[b]{2}{*}{$\begin{array}{l}\text { Value Found } \\
\text { (RSD) }\end{array}$} \\
\hline & $\begin{array}{l}\text { Analytical } \\
\text { Value }\end{array}$ & $\begin{array}{c}\text { Acceptable } \\
\text { Value }\end{array}$ & & $\begin{array}{l}\text { Analytical } \\
\text { Value }\end{array}$ & $\begin{array}{c}\text { Acceptable } \\
\text { Value }\end{array}$ & \\
\hline $\mathrm{Li}(\mathrm{mg} / \mathrm{L})$ & $0.001^{*}$ & & nd & $10.950 \pm 969$ & $10.293-11.607$ & $14.338(1.286)$ \\
\hline $\operatorname{Mn}(\mu g / L)$ & $20.1 \pm 1.9$ & $16.3-23.9$ & nd & $19.9 \pm 1.1$ & $17.7-22.1$ & nd \\
\hline $\operatorname{Co}(\mu g / L)$ & $0.23 \pm 0.074$ & $0.12-0.34$ & nd & $3.2 \pm 0.2$ & $2.8-3.6$ & nd \\
\hline $\mathrm{Cu}(\mathrm{mg} / \mathrm{L})$ & $0.645 \pm 0.02$ & $0.60-0.689$ & $0.857(2.95)$ & $2.887 \pm 0.099$ & $2.689-3.085$ & $3.102(5.296)$ \\
\hline $\mathrm{Zn}(\mathrm{mg} / \mathrm{L})$ & $4.906 \pm 0.17$ & $4.55-5.26$ & 3.760 & $2.520 \pm 206$ & $2.108-2932$ & $1.903(2.807)$ \\
\hline As $(\mu g / L)$ & $5.5 \pm 1.4$ & $2.7-8.3$ & nd & $0.67^{*}$ & & nd \\
\hline Se $\mu g / L)$ & $75 \pm 20$ & $35-115$ & nd & $163 \pm 10$ & $143-183$ & nd \\
\hline $\operatorname{Sr}(\mu \mathrm{g} / \mathrm{L})$ & $24^{*} \pm 2$ & & nd & $36.3^{*}$ & & nd \\
\hline $\operatorname{Mo}(\mu \mathrm{g} / \mathrm{L})$ & $0.8 \pm 0.16$ & $0.56-1.04$ & nd & $0.9^{*}$ & & nd \\
\hline $\mathrm{Cd}(\mu \mathrm{g} / \mathrm{L})$ & $0.67 \pm 0.04$ & $0.59-0.75$ & nd & $0.13^{*}$ & & nd \\
\hline $\mathrm{Fe}(\mathrm{mg} / \mathrm{L})$ & $335^{*} \pm 8$ & & $342.2(0.58)$ & $2.03 \pm 0.13$ & $1.77-2.29$ & $1.511(1.335)$ \\
\hline $\operatorname{Mg}(\mathrm{mg} / \mathrm{L}$ & $16.6^{*} \pm 0.6$ & & $17.16(2.07)$ & $40.8 \pm 4.7$ & $36.1-45.5$ & 36.7621 (1.628) \\
\hline $\mathrm{K}(\mathrm{mg} / \mathrm{L})$ & $1130^{*} \pm 22$ & & $1139.6(3.3)$ & $240^{*}$ & & $244.097(4.244)$ \\
\hline $\mathrm{Ca}(\mathrm{mg} / \mathrm{L})$ & $14.5^{*} \pm 0.4$ & & $12.23(6.08)$ & $145 \pm 8$ & $136-154$ & 139.07 (4.95) \\
\hline
\end{tabular}

nd: not detected.

RSD: relative standard deviation.

*Additional approximate values. 


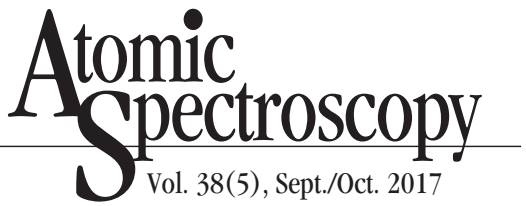

for $\mathrm{Li}$ in serum, and for Se and As in whole blood. The acid digestion methods provided good agreement for $\mathrm{Cu}$ and $\mathrm{Zn}$ in both whole blood and serum, for Fe only in whole blood, and for $\mathrm{Li}, \mathrm{K}$, and Ca only in serum. Poor agreement was obtained with the recommended values for Mo and Cd with both sample preparation methods. Although these elements were over $85 \%$ to $95 \%$ ionized in the Ar plasma, low Mo and Cd levels could not be determined by ICP-MS with any of the sample preparation methods. Similarly, low Co levels in blood and low As levels in serum could not be determined by ICP-MS (4).

For Mn, good agreement was obtained with the recommended values using Method 3 in blood and serum, and higher concentrations than the recommended values with Method 1 and Method 2. With the digestion, low analyte signal was affected by mistakes in acid digestion caused by the large volume of the final extract in the acid digestion $(0.5 \mathrm{~g}$ sample and $100 \mathrm{~mL}$ final extract). Thus, the acid digestion method provided higher accuracy than the dilution method for blood and serum.

For $\mathrm{Sr}$ and $\mathrm{Mg}$, good agreement was obtained with the recommended values with Method 3 in blood and serum. For Sr, lower concentrations were obtained than the recommended values with Method 1 and Method 2 in blood and serum and for $\mathrm{Mg}$ in serum. Moreover, higher concentrations than the certified values for $\mathrm{Mg}$ in blood were obtained with the digestion methods. With digestion, low analyte signals are affected by mistakes in the acid digestion and high analyte signals are susceptible to suppression from other matrix species. Also it is important to note that $\mathrm{Mg}$ is very common in nature, so that contamination can be a problem because it is so ubiquitous. All of these factors may have contributed to the inconsistency in the results
TABLE VII

Results of ICP-MS Analysis of Vitreous Humor Samples

\begin{tabular}{lccccc}
\hline Elements & Mean & $\begin{array}{c}\text { Standard } \\
\text { Deviation }\end{array}$ & Minimum & Maximum & Range \\
\hline $\mathrm{Li}(\mu \mathrm{g} / \mathrm{L})$ & 1.28 & 1.22 & 0.00 & 3.33 & 3.33 \\
$\mathrm{Mn}(\mu \mathrm{g} / \mathrm{L})$ & 0.24 & 0.54 & 0.00 & 1.50 & 1.50 \\
$\mathrm{Co}(\mu \mathrm{g} / \mathrm{L})$ & 0.39 & 0.99 & 0.00 & 3.30 & 3.30 \\
$\mathrm{Cu}(\mu \mathrm{g} / \mathrm{L})$ & 16.04 & 10.58 & 0.00 & 35.32 & 35.32 \\
$\mathrm{Zn}(\mathrm{mg} / \mathrm{L})$ & 0.568 & 0.323 & 0.015 & 1.003 & 0.987 \\
$\mathrm{As}(\mu \mathrm{g} / \mathrm{L})$ & 1.28 & 1.66 & 0.00 & 4.42 & 4.42 \\
$\mathrm{Se}(\mu \mathrm{g} / \mathrm{L})$ & 5.49 & 3.27 & 0.00 & 9.15 & 9.15 \\
$\mathrm{Sr}(\mu \mathrm{g} / \mathrm{L})$ & 44.32 & 17.51 & 15.24 & 66.38 & 51.14 \\
$\mathrm{Mo}(\mu \mathrm{g} / \mathrm{L})$ & 0.00 & 0.00 & 0.00 & 0.00 & 0.00 \\
$\mathrm{Cd}(\mu \mathrm{g} / \mathrm{L})$ & 0.00 & 0.00 & 0.00 & 0.00 & 0.00 \\
$\mathrm{Fe}(\mu \mathrm{g} / \mathrm{L})$ & 33.09 & 32.05 & 0.00 & 72.84 & 72.84 \\
$\mathrm{Mg}(\mathrm{mg} / \mathrm{L})$ & 24.15 & 6.16 & 12.46 & 35.23 & 22.78 \\
$\mathrm{~K}(\mathrm{mg} / \mathrm{L})$ & 410.82 & 156.59 & 176.58 & 613.85 & 437.27 \\
$\mathrm{Ca}(\mathrm{mg} / \mathrm{L})$ & 34.86 & 23.21 & 4.25 & 78.87 & 74.61 \\
\hline
\end{tabular}

TABLE VIII

Results of ICP-OES Analysis of Vitreous Humor Samples

\begin{tabular}{lrcrrr}
\hline Elements & Mean & $\begin{array}{c}\text { Standard } \\
\text { Deviation }\end{array}$ & Minimum & Maximum & Range \\
\hline $\mathrm{Mg}(\mathrm{mg} / \mathrm{L})$ & 24.45 & 6.74 & 12.17 & 34.62 & 22.45 \\
$\mathrm{~K}(\mathrm{mg} / \mathrm{L})$ & 393.77 & 138.21 & 183.32 & 591.54 & 408.22 \\
$\mathrm{Ca}(\mathrm{mg} / \mathrm{L})$ & 32.79 & 28.00 & 3.66 & 95.98 & 92.32 \\
\hline
\end{tabular}

TABLE IX

Results of the ICP-MS Analysis Certified and Found Values of Element Concentrations in Seronorm Trace Elements Whole Blood L-1

\begin{tabular}{|c|c|c|c|c|c|}
\hline \multirow[t]{2}{*}{ Elements } & \multicolumn{2}{|c|}{ Certified Value } & \multirow{2}{*}{$\begin{array}{l}\text { Method } 1 \\
\text { Value } \\
\text { Found } \\
\text { (RSD) }\end{array}$} & \multirow{2}{*}{$\begin{array}{l}\text { Method } 2 \\
\text { Value } \\
\text { Found } \\
\text { (RSD }\end{array}$} & \multirow{2}{*}{$\begin{array}{l}\text { Method } 3 \\
\text { Value } \\
\text { Found } \\
\text { (RSD }\end{array}$} \\
\hline & $\begin{array}{l}\text { Analytical } \\
\text { Value }\end{array}$ & $\begin{array}{c}\text { Acceptable } \\
\text { Value }\end{array}$ & & & \\
\hline $\operatorname{Mn}(\mu \mathrm{g} / \mathrm{L})$ & $20.1 \pm 1.9$ & $16.3-23.9$ & $37.66(2.3)$ & $38.69(1.6)$ & $19.01(2.9)$ \\
\hline $\operatorname{Co}(\mu \mathrm{g} / \mathrm{L})$ & $0.23 \pm 0.074$ & $0.12-0.34$ & nd & nd & nd \\
\hline $\mathrm{Cu}(\mathrm{mg} / \mathrm{L})$ & $0.645 \pm 0.022$ & $0.601-0.689$ & $0.768(3.9)$ & $0.670(4.8)$ & $0.653(1.7)$ \\
\hline $\mathrm{Zn}(\mathrm{mg} / \mathrm{L})$ & $4.906 \pm 0.177$ & $4.552-5.260$ & $4.921(2.0)$ & $4.709(2.4)$ & $5.026(2.4)$ \\
\hline As $(\mu \mathrm{g} / \mathrm{L})$ & $5.5 \pm 1.4$ & $2.7-8.3$ & nd & nd & $5.94(19.3)$ \\
\hline $\operatorname{Se}(\mu \mathrm{g} / \mathrm{L})$ & $75 \pm 20$ & $35-115$ & nd & nd & $73.229(1.4)$ \\
\hline $\operatorname{Sr}(\mu \mathrm{g} / \mathrm{L})$ & $24^{*} \pm 2$ & & nd & nd & $24.71(1.8)$ \\
\hline $\operatorname{Mo}(\mu \mathrm{g} / \mathrm{L})$ & $0.8 \pm 0.16$ & $0.56-1.04$ & nd & nd & nd \\
\hline $\mathrm{Cd}(\mu \mathrm{g} / \mathrm{L})$ & $0.67 \pm 0.04$ & $0.59-0.75$ & nd & nd & nd \\
\hline $\mathrm{Fe}(\mathrm{mg} / \mathrm{L})$ & $335^{*} \pm 8$ & & $345.94(2.3)$ & $340.38(1.0)$ & $303.4(2.2)$ \\
\hline $\operatorname{Mg}(\mathrm{mg} / \mathrm{L}$ & $16.6^{*} \pm 0.6$ & & $27.80(8.6)$ & $22.71(5.6)$ & $17.03(2.2)$ \\
\hline $\mathrm{K}(\mathrm{mg} / \mathrm{L})$ & $1130^{*} \pm 22$ & & $1306.6(9.1)$ & $1253.1(2.3)$ & $1226.9(1.8)$ \\
\hline $\mathrm{Ca}(\mathrm{mg} / \mathrm{L})$ & $14.5^{*} \pm 0.4$ & & $32.12(2.34)$ & $22.15(4.8)$ & $14.1(1.9)$ \\
\hline
\end{tabular}

nd: not detected.

RSD: relative standard deviation.

*Additional approximate values. 
TABLE X

Results of ICP-MS Analysis. Certified and Found Values of Element Concentrations in Seronorm Trace Elements Serum L-2

\begin{tabular}{|c|c|c|c|c|c|}
\hline \multirow[t]{2}{*}{ Elements } & \multicolumn{2}{|c|}{ Certified Value } & \multirow{2}{*}{$\begin{array}{l}\text { Method } 1 \\
\text { Value } \\
\text { Found } \\
\text { (RSD\%) }\end{array}$} & \multirow{2}{*}{$\begin{array}{l}\text { Method } 2 \\
\text { Value } \\
\text { Found } \\
\text { (RSD\%) }\end{array}$} & \multirow{2}{*}{$\begin{array}{l}\text { Method } 3 \\
\text { Value } \\
\text { Found } \\
\text { (RSD\%) }\end{array}$} \\
\hline & $\begin{array}{l}\text { Analytical } \\
\text { Value }\end{array}$ & $\begin{array}{l}\text { Acceptable } \\
\text { Value }\end{array}$ & & & \\
\hline $\operatorname{Mn}(\mu \mathrm{g} / \mathrm{L})$ & $19.9 \pm 1.1$ & $17.7-22.1$ & $32.80(4.4)$ & $31.49(3.7)$ & $20.86(0.3)$ \\
\hline $\operatorname{Co}(\mu \mathrm{g} / \mathrm{L})$ & $3.2 \pm 0.2$ & $2.8-3.6$ & $9.79(6.8)$ & $2.140(2.9)$ & $4.277(4.5)$ \\
\hline $\mathrm{Li}(\mathrm{mg} / \mathrm{L})$ & $10.95 \pm 0.969$ & $10.293-11.607$ & $11.286(1.2)$ & $11.197(1.6)$ & $10.945(2.0)$ \\
\hline $\mathrm{Cu}(\mathrm{mg} / \mathrm{L})$ & $2.887 \pm 99$ & $2.689-3.085$ & $3.048(1.4)$ & $2.952(1.2)$ & $2.903(1.6)$ \\
\hline $\mathrm{Zn}(\mathrm{mg} / \mathrm{L})$ & $2.520 \pm 206$ & $2.108-2.932$ & $3.544 .3(2.2)$ & $2.275(1.0)$ & $2.422(3.2)$ \\
\hline As $(\mu \mathrm{g} / \mathrm{L})$ & $0.67^{*}$ & & nd & nd & nd \\
\hline $\operatorname{Sr}(\mu \mathrm{g} / \mathrm{L})$ & $36.3^{*}$ & & $4.85(1.5)$ & $11.65(8.2)$ & $37.82(1.8)$ \\
\hline $\operatorname{Mo}(\mu \mathrm{g} / \mathrm{L})$ & $0.9^{*}$ & & nd & nd & nd \\
\hline $\mathrm{Cd}(\mu \mathrm{g} / \mathrm{L})$ & $0.13^{*}$ & & nd & nd & nd \\
\hline $\mathrm{Fe}(\mathrm{mg} / \mathrm{L})$ & $2.03 \pm 0.13$ & $1.77-2.29$ & $3.22(1.8)$ & $6.12(1.0)$ & $2.32(1.0)$ \\
\hline $\mathrm{Mg}(\mathrm{mg} / \mathrm{L}$ & $40.8 \pm 4.7$ & $36.1-45.5$ & $30.85(3.2)$ & $25.69(1.6)$ & $44.13(3.9)$ \\
\hline $\mathrm{K}(\mathrm{mg} / \mathrm{L})$ & $240^{*}$ & & $236.5(1.8)$ & $252.87(2.8)$ & $246.85(1.7)$ \\
\hline $\mathrm{Ca}(\mathrm{mg} / \mathrm{L})$ & $145 \pm 8$ & $136-154$ & $138.0(0.9)$ & $138.37(2.9)$ & $142.6(1.1)$ \\
\hline
\end{tabular}

nd: not detected.

RSD relative standard deviation.

*Additional approximate values.

obtained with the digestion methods.

Better agreement with the recommended values for $\mathrm{Fe}$ in the blood sample was obtained with both sample preparation methods, which contained much higher Fe concentrations $(335 \mathrm{mg} / \mathrm{L})$ than the serum sample $(2.15 \mathrm{mg} / \mathrm{L})$. However, agreement with the recommended value was better for $\mathrm{Ca}$ in the serum reference sample, which contained a higher Ca concentration $(145 \mathrm{mg} / \mathrm{L})$ than the blood sample $(14.5 \mathrm{mg} / \mathrm{L})$. As is already known, Fe can be difficult to determine by ICP-MS since all four isotopes suffer from isobaric or polyatomic interference. Plasmaderived polyatomics interfere with three of the four stable iron isotopes and in calcium-rich samples, isobaric interferences are common. The reaction collision cell with helium cell gas removes all polyatomic interferences without creating new interferences.
Measurement of three isotopes, however, is a necessary quality control technique to identify isobaric interferences in the samples. For the analysis of calcium, the ${ }^{40} \mathrm{Ca}$ isotope and the ${ }^{44} \mathrm{Ca}$ isotope are subject to interference from ions in the plasma which severely degrades the detection limit for this isotope. Normally, Ca is very difficult to determine at low levels. Both, the dilution method (Method 3 ) and the digestion methods (Method 1 and Method 2) showed good agreement with the recommended values for $\mathrm{Ca}$ in the serum samples, however, only the dilution method for the blood samples. The digestion methods provided higher results than the recom-mended values in blood by mistake in acid digestion (4).

The dilution method provided similarly good agreement with the recommended values of the reference materials for the 10 elements in blood and serum. However, the digestion method only showed good agreement for four elements in blood and five in serum. The two certified reference materials were prepared by dilution with ultrapure water and analyzed by ICP-OES, and the results are listed in Table VI. Good agreement was obtained with the recommended values for $\mathrm{Fe}$, $\mathrm{Mg}, \mathrm{K}$, and $\mathrm{Ca}$ in both whole blood and serum; for $\mathrm{Cu}$ in serum, and for $\mathrm{Zn}$ the values were much closer in blood and serum. As can be observed, better results were obtained with ICP-MS than with ICP-OES (14-18).

Currently, the two techniques are applied to the analysis of clinical matrices for their rapid multielement capability, wide elemental coverage and dynamic range, their suitability for small sample volumes, and ease of use. In ICP-MS, the collision/reaction cell eliminates or significantly reduces the effects of polyatomic interferences in complex matrices, and in ICP-OES the use of high-resolution spectrometers and advanced background correction techniques, coupled with the flexibility to choose from many possible emission lines, allows for interference-free analyses of most samples. Moreover, the two techniques are applicable to the determination of a large number of elements, which is most of the over 70 elements that can be determined by ICP-OES and ICP-MS. Inductively coupled plasma mass spectrometry has the advantage of achieving very low detection limits and so it is the technique of choice for trace elemental analysis. Likewise, if the application calls for multi-element analysis of samples in a complicated matrix or if a high sample throughput rate with moderate sensitivity is required, then ICP-OES might be the best choice $(4,9-18)$.

\section{Analysis of Collected Human Vitreous Humor Samples}

A comparison of the element concentrations in the collected 


\section{Atomic Spectroscopy \\ $\bigcirc$ Vol. 38(5), Sept./Oct. 2017}

vitreous humor samples analyzed by the two elemental techniques is given in Tables VII and VIII.

In vitreous humor samples, almost all elements analyzed by ICP-MS showed very low concentrations (Li, Mn, Co, Se, and As), while for Cd and Mo no signal was detected. $\mathrm{Cu}, \mathrm{Sr}$, and $\mathrm{Fe}$ showed higher concentrations but below $45 \mu \mathrm{g} / \mathrm{L}$ and $\mathrm{Zn}$ around $0.5 \mathrm{mg} / \mathrm{L}$. On the other hand, $\mathrm{Mg}, \mathrm{K}$, and $\mathrm{Ca}$ showed very high concentration levels $(4,9-13)$.

For almost all of the elements analyzed by ICP-OES, no signal was detected except for the three elements of highest concentration: $\mathrm{K}$, Ca, and $\mathrm{Mg}$. These results are due to two reasons: on the one hand, the detection limits are not very low and the sensitivity of the technique is moderate, and on the other, it is necessary to dilute the samples before analysis because of the consistency, nature, and the high viscosity of the vitreous humor (14-18).

A linear regression analysis was carried out to verify the relationship between the two analytical techniques for the determination of $\mathrm{Mg}, \mathrm{K}$, and $\mathrm{Ca}$ in vitreous humor samples (Table XI). Linear regression plots of concentration results with ICP-MS vs. ICP-OES in vitreous humor samples are shown in Figures 1-3.

The regression analyses showed very good correlation between the two methods $\left(R^{2}>0.90\right)$ for $\mathrm{K}$ and similar concentrations
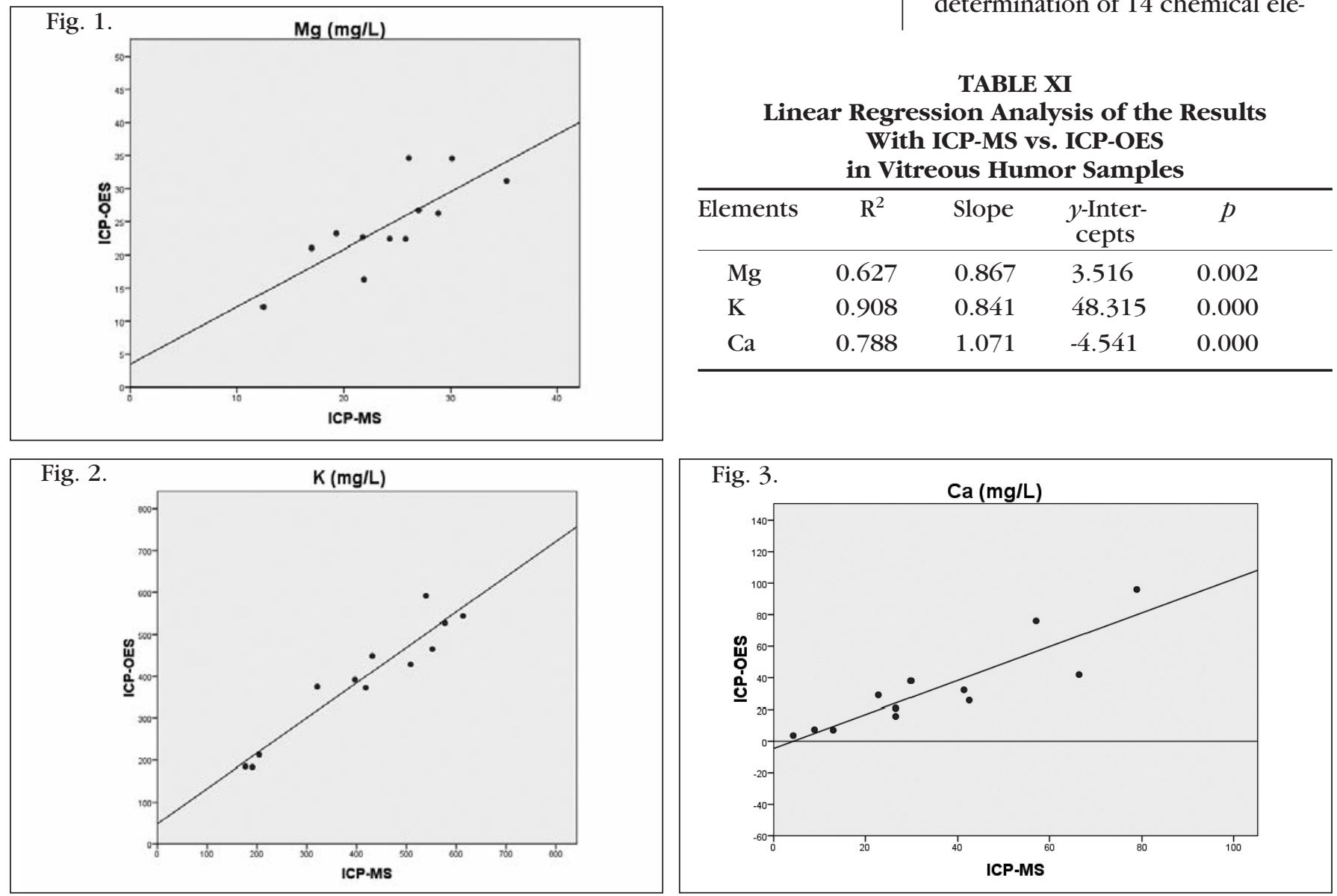

Fig. 1-3. Linear regression plots of concentration results with ICP-MS technique vs. ICP-OES technique in vitreous humor samples. 
ments in vitreous humor samples using the ICP-MS technique. It was concluded that the dilution method provided good agreement with the recommended values in the certified reference materials for 10 elements in blood and serum (Fe, Mg, $\mathrm{K}, \mathrm{Ca}, \mathrm{Mn}, \mathrm{Cu}, \mathrm{Zn}$, and $\mathrm{Sr}$; Se and $\mathrm{As}$ in blood; and Li in serum), while the digestion method only showed good agreement for four elements $(\mathrm{Cu}, \mathrm{Zn}, \mathrm{Fe}$, and $\mathrm{K})$ in blood and five $(\mathrm{Li}, \mathrm{Cu}, \mathrm{Zn}, \mathrm{K}$, and $\mathrm{Ca}$ ) in serum. Therefore, the dilution method seems to be the pretreatment of choice for multi-element determination in biological fluids by ICP-MS, while the acid digestion method is only suitable for fluids with high element concentrations.

ICP-OES analysis of diluted reference materials showed good agreement with the reference values for $\mathrm{Fe}, \mathrm{Mg}, \mathrm{K}$ and $\mathrm{Ca}$, poor agreement for $\mathrm{Cu}, \mathrm{Zn}$, and $\mathrm{Li}$, and no agreement for the remaining elements studied.

As can be observed, better results were obtained with ICP-MS than with ICP-OES. Analysis of the vitreous humor samples by ICP-MS pointed to very low concentrations for almost all of the elements analyzed. Only $\mathrm{K}$, Ca, and $\mathrm{Mg}$, which had higher concentrations, were detected by ICP-OES. The regression analyses showed good correlation between the two analytical techniques studied for the determination of $\mathrm{Mg}, \mathrm{K}$, and $\mathrm{Ca}$ in vitreous humor samples.

It can be stated that multi-element analysis of vitreous humor samples is complicated. On the one hand, the high viscosity of this clinical fluid requires pre-treatment of the samples, and the present studies demonstrate that the dilution method requires a small sample volume, is faster, and shows better reproducibility than the digestion method. On the other hand, almost all chemical elements analyzed in the vitreous humor samples had very low concentrations. For their detection and quantification, a technique is required that allows the measurement of trace and ultratrace elements in biological matrices, and the technique must have high sensitivity and low detection limits. ICP-MS can be considered such a technique.

\section{ACKNOWLEDGMENTS}

The authors gratefully acknowledge the infrastructure support of the Assistance Service of Technological Research of the Technical University of Cartagena (Spain) and the Forensic Pathology Service of Institute of Legal Medicine of Cádiz (Spain).

This research did not receive any specific grants from funding agencies of the public, commercial, or non-profit sectors.

Received February 27, 2017.

\section{REFERENCES}

1. M.D. Pérez-Cárceles, A. Sibón, M.L. Gil del Castillo, M.A. Vizcaya, E. Osuna, T. Casas, J.L. Romero, and A. Luna, Biol. Trace Elem. Res. 126, 27 (2008).

2. M.D. Pérez-Cárceles, S. del Pozo, A. Sibón, J.A. Noguera, E.Osuna, M.A. Vizcaya and A. Luna, Forensic Sci. Int. 214,159 (2012).

3. P. Heitland and H.D. Köster, Clin. Chim. Acta 365, 310 (2006).

4. G. Li, J.D. Brockman, S. Lin, C.C. Abnet, L.A. Schell and J.D. Robertson, Am. J. Anal. Chem. 3, 646 (2012).

5. A.Thierauf, F. Musshoff and B. Madea, Forensic Sci. Int. 192, 78 (2009).

6. S.A. Balana, F. Mußhoff, T. Hoeller, R. Fimmers and B. Madea, Forensic Sci. Int. 21,1 (2011).

7. A.D. Cala, R. Vilain and R. Tse, Am. J. Forensic Med. Pathol. 34, 133 (2013).

8. J. Garland, R. Tse, C. Oldmeadow J.
Attia, S. Anne and A.D. Cala, Forensic Sci. Int. 266, 338 (2016).

9. Y. Lu, M. Kippler, F. Harari, M .Grandér, B. Palm, H. Nordqvist and M. Vahter, Clini. Biochem. 48, 140 (2015)

10. P. Heitland and H.D. Köster, J. Trace Elem. Med. Biol. 20, 253 (2006).

11. E. McCurdy and G. Woods, J. Anal. At. Spectrom.19, 607 (2004).

12. S. Millour, L.Nöel, A. Kadar, R.Chekri, C. Vastel and T. Guérin, J. Food Comp. Anal. 2, 111 (2011).

13. A. Agazzi and C. Pirola, Microchem. J. 67, 337 (2000).

14. J.A.C. Broekaert. Inductively Coupled Plasma Spectrometry. In: G. Gauglitz and D. S. Moore (eds.) Handbook of Spectroscopy: Second, Enlarged Edition. Weinheim, Germany, Wiley-VCH Verlag GmbH \& Co., KgaApp. 583-646, (2014).

15 V. Padmasubashini and G. Chakrapani, At. Spectrosc. 37, 229 (2016).

16. R.E.S. Froes, W. Borges, C.C. Nascentes and J.B.B. Silva, At. Spectrosc. 36, 7 (2015).

17. R. Rahil-Khazen, B.J. Bolann and R. J. Ulvik, BioMetals 15, 87 (2002).

18. R. Rahil-Khazen, B. J.Bolann, A. Myking and R. J.Ulvik, J. Trace Elem. Med. Biol. 16, 15 (2002). 